\title{
The Potential of Dipterocarpaceae in the Karst of Sangkulirang Mangkalihat
}

\author{
Rifani ${ }^{1}$ Matius Paulus ${ }^{1}$ Hastaniah $^{1}$ Sutedjo ${ }^{1}$ Raharjo Ari Swasono ${ }^{1}$ Rita Diana ${ }^{1, *}$ \\ ${ }^{1}$ Faculty of Forestry, Mulawarman University, Kampus Gn. Kelua Jl. Ki Hajar Dewantar, Samarinda, Indonesia \\ *Corresponding author. Email: ritadiana@fahutan.unmul.ac.id
}

\begin{abstract}
The Dipterocarpaceae are very dominant in the Kalimantan forest, which has an important role in economic and conservation aspects. The aim of this research is to determine the potential of Dipterocarpaceae at karst Sangkulirang - Mangkalihat in Berau and Kutai Timur Regency. The research is about two months in six locations. The plotting method is using the purposive sampling method, and 15 plots were made at each location. The number of Dipterocarpaceae species found is 31 species comprising 174 individuals in 7 genera, such as Anisoptera spp., Dipterocarpus spp., Dryobalanops spp., Hopea spp., Parashorea spp., Shorea spp., and Vatica spp. Genera that was not found, i.e., Cotylelobium spp. and Upuna spp. The number of potential Dipterocarpaceae tree species found is 95 individuals (105 individuals per hectare) with a basal area of $67.59 \mathrm{~m}^{2}$ per hectare and $129.65 \mathrm{~m}^{3}$ volume per hectare. The number of sapling species found is 52 individuals (253 individuals per hectare) and 28 individuals (3111 individuals per hectare).
\end{abstract}

Keywords: Dipterocarpaceae, potential, Karst Sangkulirang-Mangkalihat

\section{INTRODUCTION}

Limestone hill forest ecosystem is one of the unique lowland rain forest ecosystems because it has morphological conditions and rock natures different from the other ecosystem types [1]. Limestone hill forests generally have few plants and species. Dipterocarpaceae are the leading timber producer trees of tropical rain forests in western Indonesia, Malaysia, Brunei, and the Philippines and spread eastward to Irian Jaya and Papua New Guinea. The timber industry found that most genera from the Dipterocarpaceae family were difficult to identify, especially in Borneo Island, since they have a high number of species [2].

In Borneo Island, there are nine genera of the Dipterocarpaceae family. Of 268 species and 27 subspecies were recorded. Of 113 species, among them are endemic to the island of Borneo. The nine genera of the Dipterocarpaceae family found on Borneo's island are Anisoptera, Dipterocarpus, Dryobalanops, Cotylelobium, Hopea, Parashorea, Shorea, Upuna, and Vatica [2].

\section{RESEARCH METHODS}

The research was carried out for two months in 6 locations, i.e., Biatan Ulu, Suaran, Lubang Kelatak, Biduk-biduk (Teluk Sulaiman), Tondoyan, and Gergaji. The plotting method was done using the purposive sampling method, with a plot size of $10 \times 10 \mathrm{~m}$ for trees, $5 \times 5 \mathrm{~m}$ for a sapling, and $1 \times 1 \mathrm{~m}$ for seedlings. Fifteen plots were made at each location. The data recorded were for the tree (species name, diameter, height, number of individuals), for the sapling (species name, number of individuals), and the seedling (species name, number of individuals). 


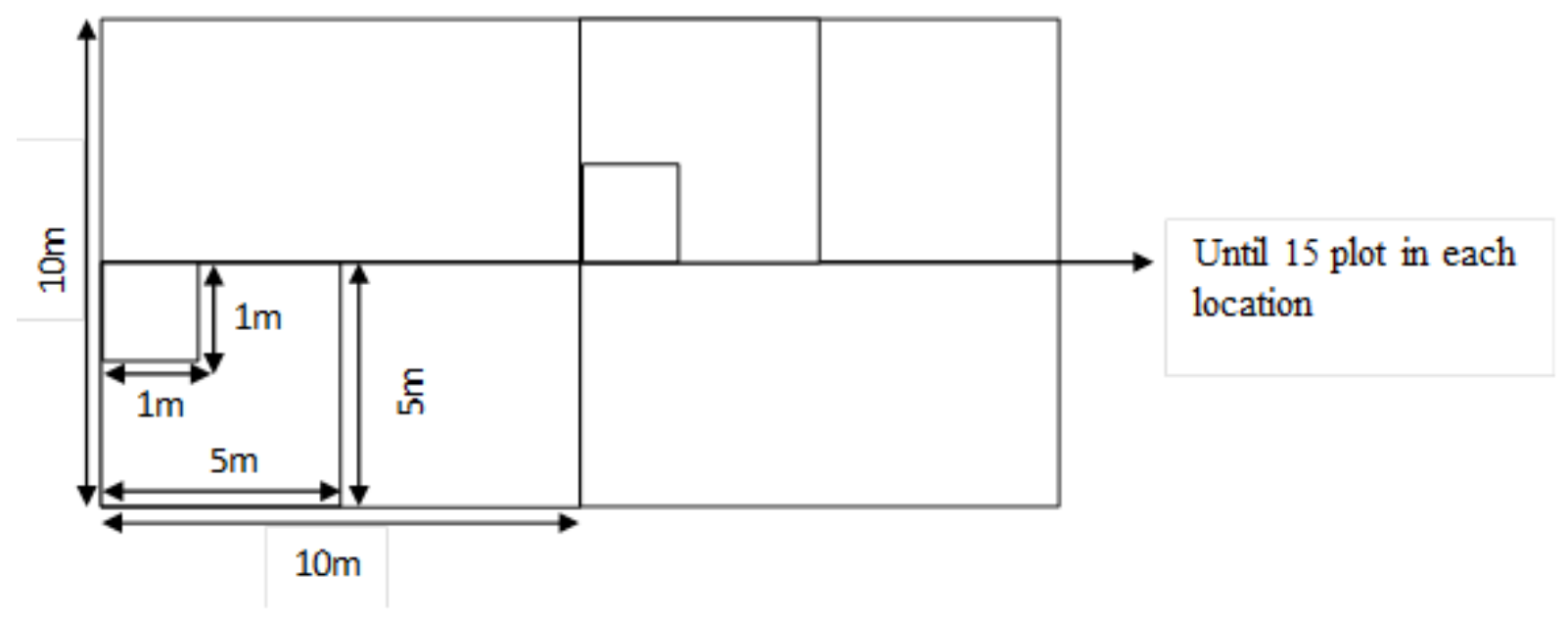

Figure 1 The scheme of making plot

\section{RESULT AND DISCUSSION}

\subsection{Potential of the Family Dipterocarpaceae}

There were 31 species of 7 genera of the Dipterocarpaceae in karst Sangkulirang Mangkalihat, i.e., Anisoptera spp., Dipterocarpus spp., Dryobalanops spp., Hopea spp., Parashorea spp., Vatica spp., Shorea spp. The genus of Cotylelobium spp. and Upuna spp. were not found. The number of Dipterocarpaceae potential stands is 174 individuals subdivided into several levels, including trees, saplings, and seedlings. There are 95 individuals (105 N/Ha) with a basal area of 67.59 per hectare and a volume of $129.65 \mathrm{~m}^{3}$ per hectare for tree level. The number of sapling levels is 51 individuals $(253 \mathrm{~N} / \mathrm{Ha})$ and 28 individuals for seedlings $(3,111 \mathrm{~N} / \mathrm{Ha})$. It can be seen in more detail in Figure 2 .

In 6 locations, Biatan Ulu and Suaran have a quite high potential because these two areas are still in the primary forest category because they are still in good conditions and lack community activities. Besides, Lubang Kelatak and Biduk-biduk (Teluk Sulaiman) are categorized as old secondary forests; several illegal logging activities by the surrounding community might disturb the forest. The Tondoyan and Gergaji have the low potential of the Dipterocarpaceae family. According to residents during the great fires in 1982 and 1998, these two regions were also burned at the time, which made the Dipterocarpaceae family's development process stunted.

\subsection{Dipterocarpaceae Stand Structure}

\subsubsection{Horizontal Structure}

Tree diameter distribution is dominated by trees with diameters between $10-20 \mathrm{~cm}$, where the number decreases when it reaches a larger diameter. When drawn from the graph above, it can be seen that the horizontal structure of forest stands in the six study sites forms an inverted J-like curve where individuals of each diameter class decrease with the size of the tree diameter. These changes are caused by the speed of growth and variations in growing space needed in tree growth so that competition and natural selection occur, both among similar and different species. This is what causes changes in the distribution of trees in forest stands. The above statement is supported [3], which states that in a non-lifetime stand, the frequency distribution of the number according to its diameter class will form an inverse J-curve.

\subsubsection{Vertical Structure}

Stratification can be determined based on the height of the vegetation canopy, [4] divided stratification into three strata, i.e., stratum A (height $>30 \mathrm{~m}$ ), stratum B (height 20-30 m), and stratum C (height 4-20 m). Stratification in forest stands occurs due to differences in age and competition between one particular type and another, forming a vertical structure [5].

The vertical structure of Dipterocarpaceae stands (diameter $10 \mathrm{~cm}$ and over) has three strata (A, B, and C), where strata with the height of 4-20 m always dominate each location, especially in primary forest areas (Biatan Ulu and Suaran), except Biduk-biduk (Teluk Sulaiman), which is dominated by the strata with the height of 20-30 m. This shows the regeneration of Dipterocarpaceae species is still stable and is a characteristic of dipterocarp forest which continuously varies in the age of vegetation. The difference in a stratum is due to competition between plants and the tolerance of tree species to the radiation, of the age of forest stands, in the formation of a region's strata [6]. The larger the diameter and height of the Dipterocarpaceae, the fewer individuals. Naturally, this competition reduces the number of individuals who survive at each diameter class level [7]. 


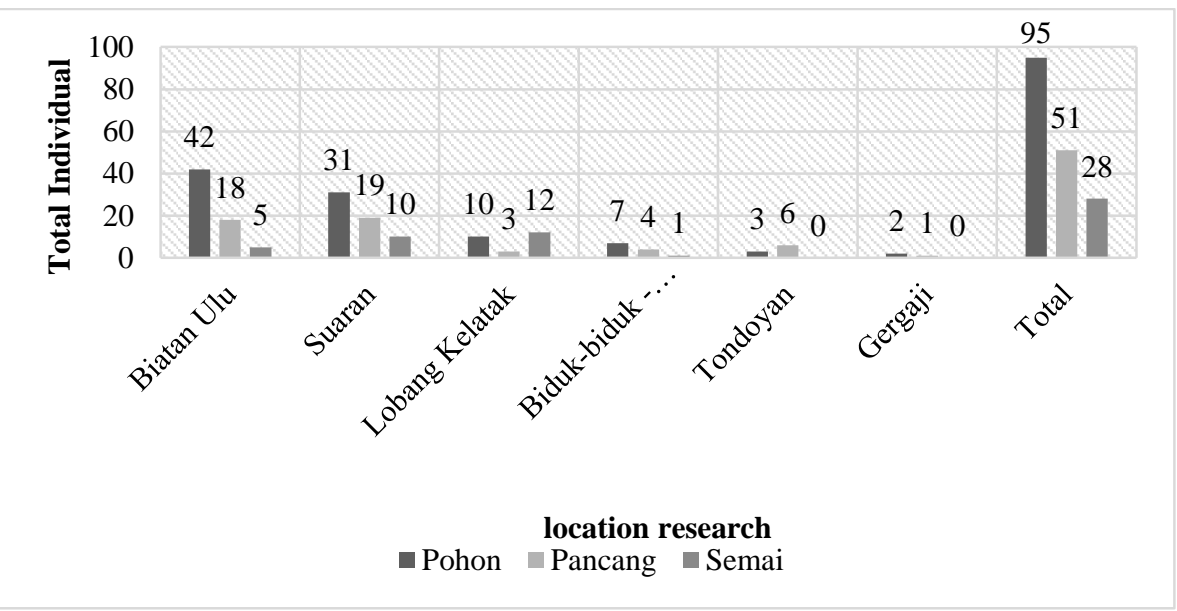

Figure 2 Potential of Stand

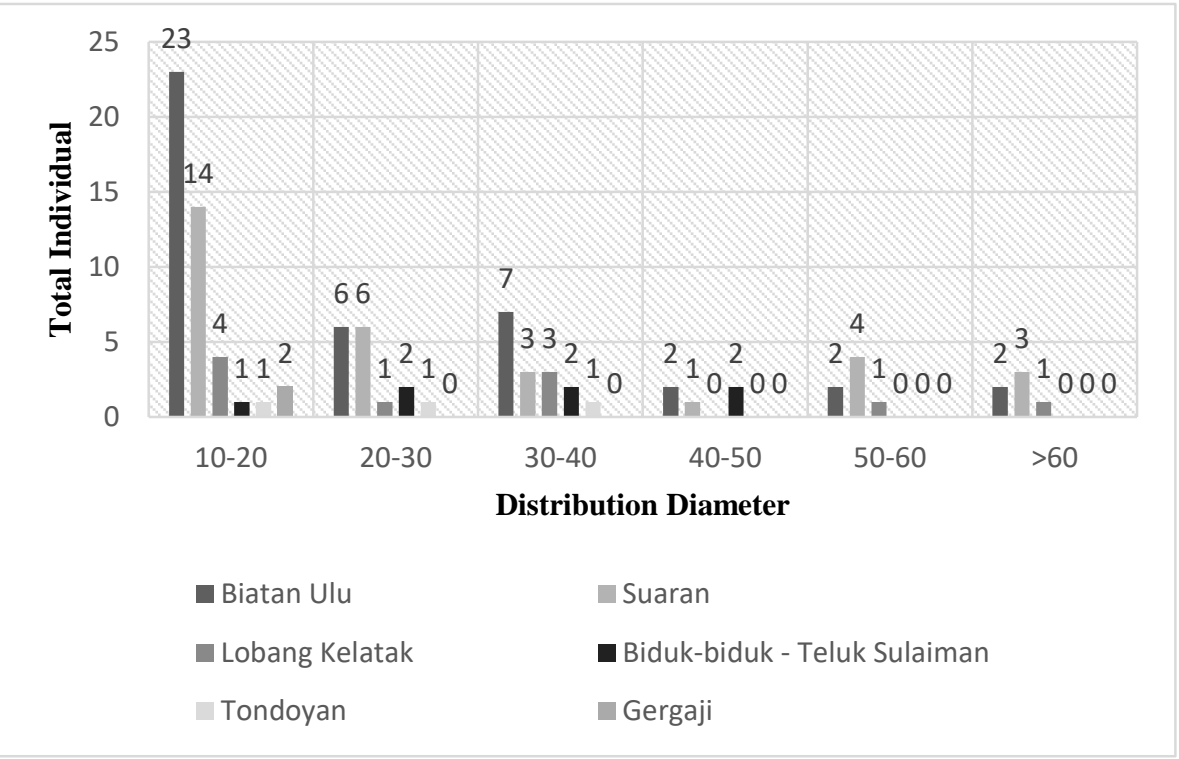

Figure 3 Picture of Tree Level Diameter Distribution Chart

\subsection{Domination of Dipterocarpaceae Species}

\subsubsection{The presence of Dipterocarpaceae Trees in the Six Locations}

From the results of the field data collection of treelevel Dipterocarpaceae analysis in six locations, there are 27 species of Dipterocarpaceae family identified where three species with individuals and the dominant frequency of presence were observed, i.e., Vatica rassak Blume, Shorea guiso (Blanco) BL., and Vatica odorata (Griff.) Symington. More details can be seen in Figure 5 .

\subsubsection{The Presence of Dipterocarpaceae Sapling in the Six Locations}

From the results of field data collection, the sapling level of Dipterocarpaceae stands at the study site contained 12 species of Dipterocarpaceae was identified in the study location where three species with individuals and the frequency of presence were dominant, That is Shorea laevis Ridl., Shorea guiso (Blanco) BL., Vatica rassak Blume. For more details, see Figure 6.

\subsubsection{The Presence of Dipterocarpaceae Seedling in All Six Locations}

From the results of field data collection, the sapling level of Dipterocarpaceae stands at the study site contained seven species of Dipterocarpaceae was identified in the study location. Where three species with individuals and the frequency of presence were dominant, that is Vatica rassak Blume, Shorea guiso (Blanco) BL., Shorea laevis Ridl. For more details, see Figure 7. 


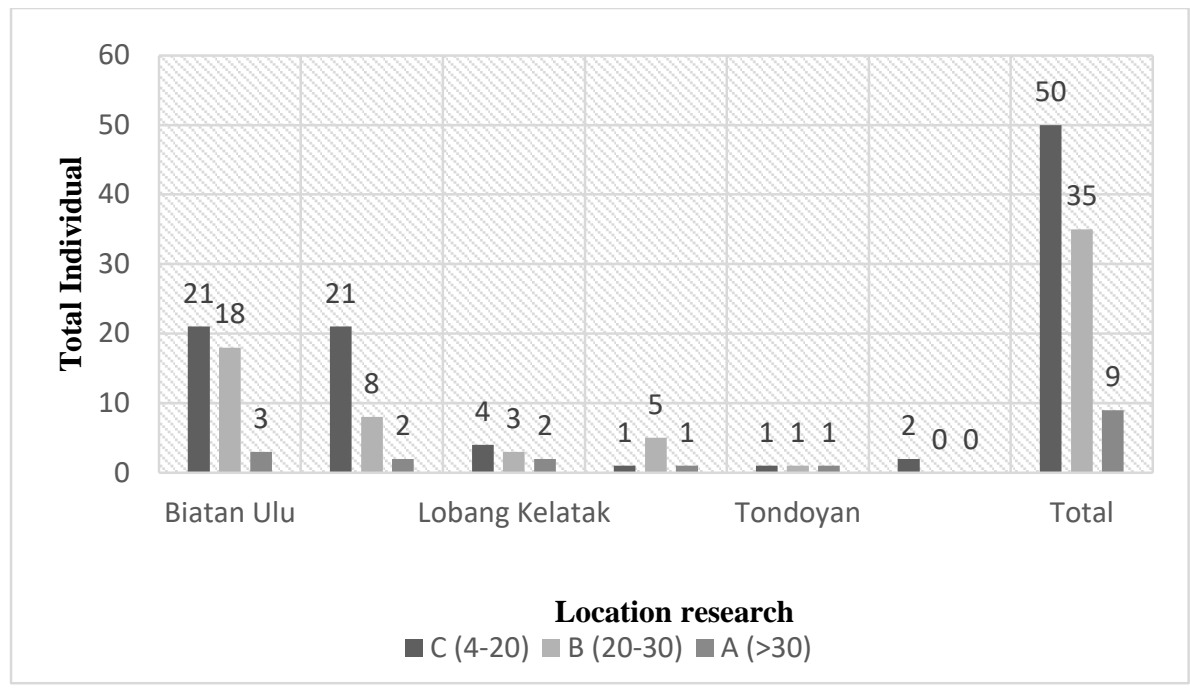

Figure 4 Chart of Stand Distribution

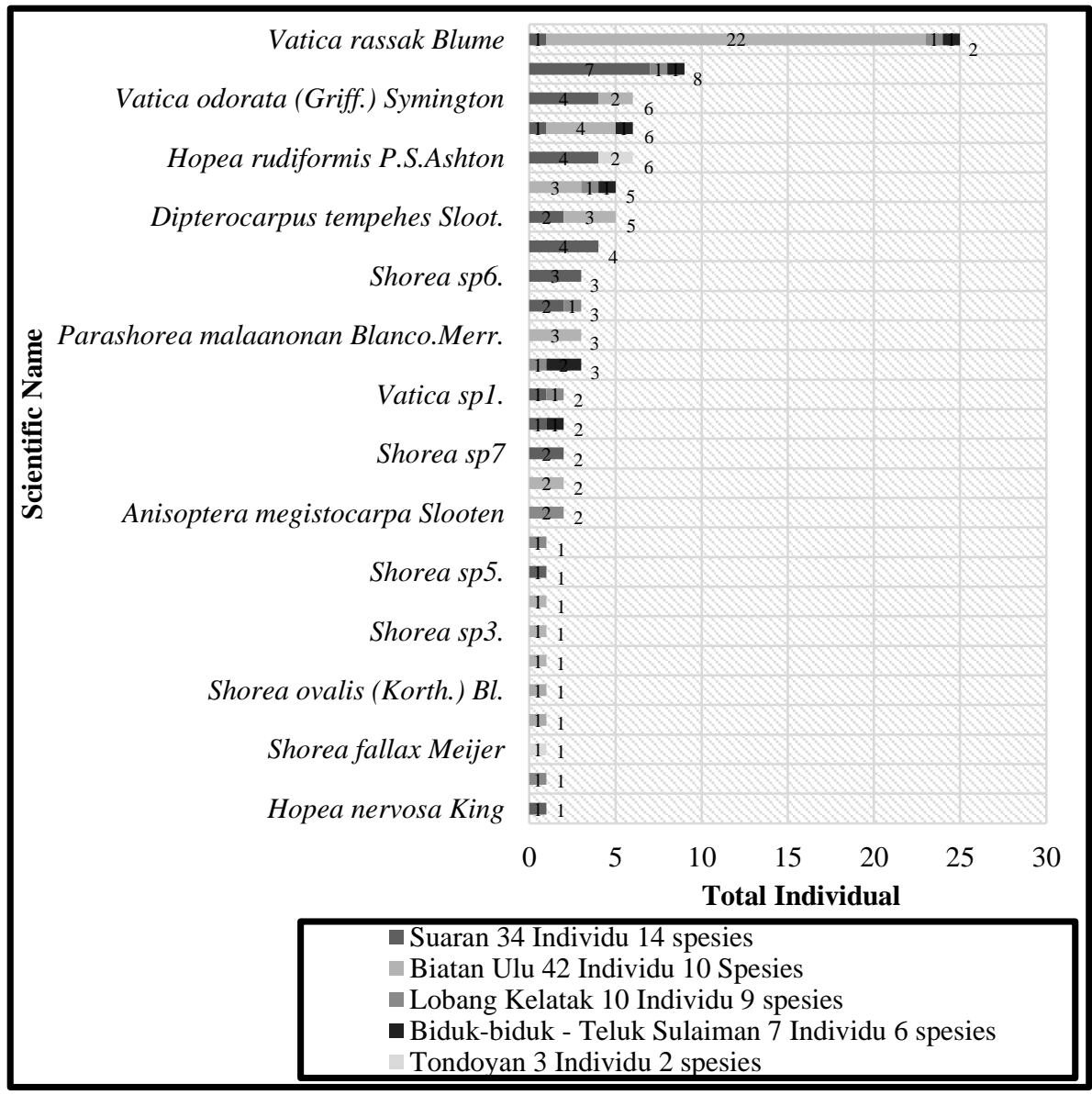

Figure 5. The Presence of Dipterocarpaceae in the Six Locations

The three images above can be seen species with individuals. Their frequency of presence is dominant at the level of trees, saplings, and seedlings, i.e., Vatica rassak Blume and Shorea guiso (Blanco) BL. This is influenced by the limestone hill forest types' ecological suitability and the dominant type of individual presence in lowland tropical rainforests under $300 \mathrm{~m}$ asl [8]. According to [9], the genus Shorea, Vatica, and Hopea are always dominant at an altitude of 500 meters above sea level with limestone hill forest types. From the 6 study sites both at the tree level, saplings, and seedlings, Suaran and Biatan Ulu's location is always dominant in the presence of individuals and species from other research locations. 


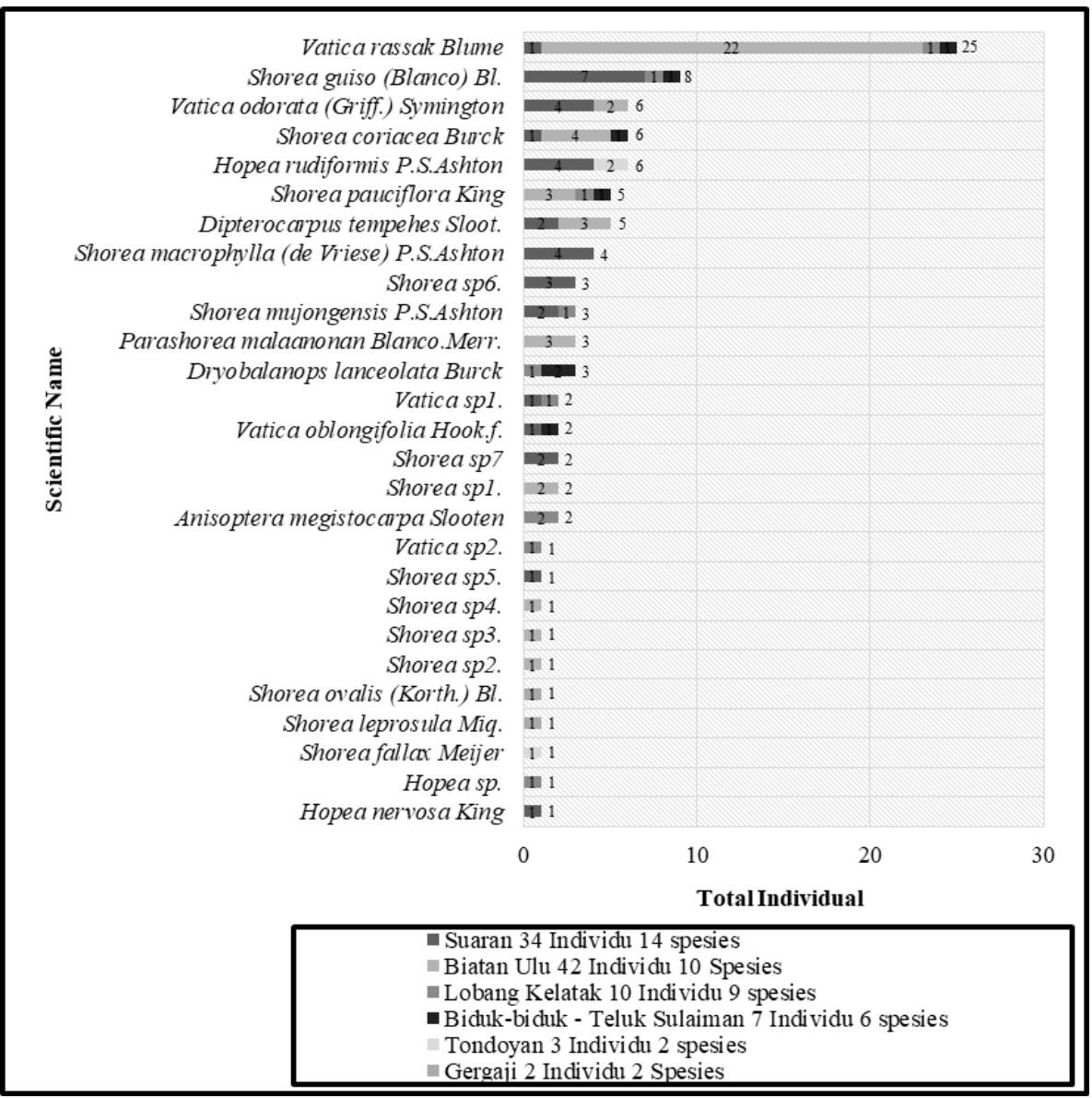

Figure 6 The Presence of Dipterocarpaceae Trees in the Six Locations

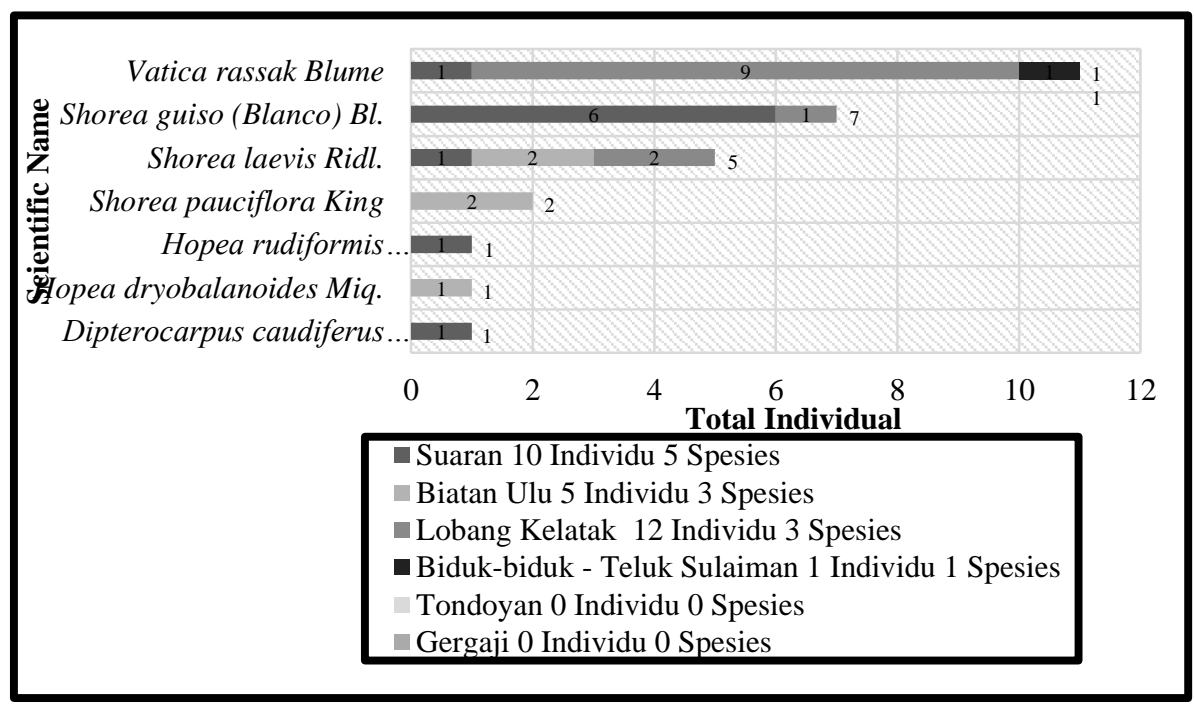

Figure 7 The Presence of Dipterocarpaceae seedlings in the Six Locations

\section{CONCLUSION}

Biatan Ulu and Suaran cultures, which are primary forests with abundant individual Dipterocarpaceae, presences the number of individual decreases with increasing diameter and height of the stand. The type that matches the ecological conditions of the limestone hill forest is Vatica rassak Blume. and Shorea guiso (Blanco) BL., because both species always present in every condition of the forest that is primary and secondary limestone hills. 


\section{ACKNOWLEDGMENT}

The author would like to thank all those who have helped in the research advance Lasmito, Zulkifli, Atma Wahyu Wiyanata, Dwi Putri Ramadhani, Maldi Nurachman, Muhammad Fajar Tegar Wahyudi, Jeka Risky Febrian, Febrian Sara TFCA Kalimantan, and Faculty of Geography, Gadjah Mada University.

\section{REFERENCES}

[1] Whitten et al., Ekologi Sulawesi, Gadjah Mada University Press, Yogyakarta, 1987.

[2] Newman dkk, Pedoman Identifikasi Pohon-Pohon Dipterocarpaceae Pulau Kalimantan, Prosea Indonesia, Bogor, 1999.

[3] Daniel et al., Prinsip-prinsip Silvikultur, Terjemahan, Edisi Ke-2, Terjemahan, Gadjah Mada University Press, Yogyakarta, 1987.

[4] I. Soerianegara, A. Indrawan, Ekologi hutan, Fakultas Kehutanan Institut Pertanian Bogor, Bogor, 1988.

[5] Tri Atmoko dkk, Structure and Distribution of Dipterocarpaceae Trees in Merapit Seed Stand, Central Kalimantan, Balai Penelitian Teknologi Konservasi Sumber Daya Alam, Samboja, Kalimantan Timur, 2011.

[6] Indriyanto, Ekologi Hutan, PT Bumi Aksara, Jakarta, 2008.

[7] S. Susanti, Komposisi Jenis dan Struktur Tegakan Regenerasi alami di Hutan Pendidikan Gunung Walet, Sukabumi, Bachelor of Forestry, Department of Silvikultur, Faculty of Forestry, Institut Pertanian Bogor, Bogor, 2014.

[8] Asthon, Tree Flora of Sabah and Sarawak, Arnold Arboretum, Harvard University Herbaria, Cambridge, Massachusetts, U.S.A. and Royal Botanic Gardens, Kew, England, UK, 1982.

[9] Purwaningsih, Ecological distribution of Dipterocarpaceae species in Indonesia, Pusat Penelitian Biologi-LIPI, Bogor, 2004. 